\title{
A Study on the Promotion of Self-Learning through Pigaiwang
}

\author{
Fang Sun ${ }^{1, a}$ and Qiang $Q u^{2, b}$ \\ ${ }^{1}$ Applied Foreign Language Department of Chengdu Neusoft University No.1 Dongruan Road, \\ Qingchengshan, Dujiangyan, Chengdu, Sichuan 611844, P.R.China \\ ${ }^{2}$ Applied Foreign Language Department of Chengdu Neusoft University No.1 Dongruan Road, \\ Qingchengshan, Dujiangyan, Chengdu, Sichuan 611844, P.R.China \\ asunfang@nsu.edu.cn, bquqiang@nsu.edu.cn
}

Keywords: Pigaiwang; Autonomous writing; Writing ability; Motivation

\begin{abstract}
English writing ability is one of the important performances of English comprehensive abilities. To find out whether Pigaiwang can help to promote students' self-learning through writing, this study will analyze the datum on this website and make some student interviews. The results show that Pigaiwang can effectively promote the process of writing, enhance the self-learning abilities, and improve writers' interest and sense of accomplishment. The conclusion is that students' autonomous writing ability could be generally promoted through Pigaiwang.
\end{abstract}

\section{Introduction}

English writing ability is not only one of the important performances of English comprehensive abilities, but also a reflection of critical thinking abilities. Writing is a useful tool for assessing the outcomes of study.[1] However, teaching writing is not an easy task, for essay marking usually takes a lot of time and energy, and what's more, it's reliability and validity is also not good.[2] Researchers designed and developed a series of automated essay scoring systems, such as PEG (Project Essay Grade), IEA (Intelligent Essay Assessor), E-rate, etc.[3] One of the most famous automated essay scoring system in China, Pigaiwang, is being adopted by more and more schools and universities. Pigaiwang is an automated essay scoring system based on language database and cloud computing. It can produce scores, comments, suggestions and analysis immediately, which aims to help students enhance their writing abilities through autonomous writing.[4] Base on empirical research this paper aims to prove whether this mode of web learning - "self-study, self-improvement"'[5] - can promote the abilities of autonomous writing.

\section{Literature Review}

Process Approach. Rather than only to provide a final score, the aim of writing is to extract themes from writer's sub-consciousness and let clear minds process them.[6] That is to say marking an essay is not only to provide a score but also to frequently make suggestions for revision, and in turn writers should repeatedly improve their essays. Furthermore, one basic principle of writing is that it should include pre-writing stage, writing stage, peer and teachers' assessment and revision. [7]

Discovery Teaching Method. American educator Bruner raised the theory that discovering the law of unknown relations and similarities of different opinions helps to promote self-confidence.[8] Only by memorizing some abstract theories, students cannot really improve their study. Instead, they usually learn better when they do some practical operations.

Role Identity. Since 1963 when Erikson introduced the concept of "Ego Identity"[9], this theory is widely used in every field. Misidentification is a big barrier to teaching English writing. Unconscious of their identity - "writers", students cannot identify their roles, and write only for finishing a writing assignment. Thus role identity is a precondition for successful writing. 


\section{Study Design}

Aims. This study aims to find out whether Pigaiwang helps to promote automated writing abilities of college students based on the analysis of functions of Pigaiwang and students' writing datum.

Objects of Study. The objects of this study are two groups of college students: Group A and B. Group A are 30 students who did not use Pigaiwang, while Group B are 30 students who used Pigaiwang. Both Group A and B are sophomores of the year 2017 in Chengdu Neusoft University, and both are not informed of this teaching experiment.

Study Methods. This study mainly adopts investigation method. Both two groups were required to submit their writings for 3 times and the writing requirements for the two groups are the same. Group A was required to submit directly to the author of this paper, while Group B submitted directly to Pigaiwang. Then the author provided comments and suggestions to Group A, while Pigaiwang provided to Group B. Next the author recorded the times of revision for both groups.

Besides, the author of this paper conducted a questionnaire survey for Group B, whose main contents include: whether the feedback of Pigaiwang is accurate; whether Pigaiwang helps to repeated writing; whether Pigaiwang promotes the learning of vocabulary and sentences; whether Pigaiwang lowers writing anxiety; whether Pigaiwang increases writing interest; whether Pigaiwang heightens the sense of achievement. Group B was also required to quantify the above six evaluation indicators by marks with "very satisfactory" "satisfactory" "average" "unsatisfactory" "very unsatisfactory". In addition, the author interviewed three students from Group B: one revised writing for 3 times, another for 8 times and the last one for 16 times.

Assessment Dimensions. This study assesses Group A and B from the following six aspects: "average times of revision", "type-token ratio"[10], "spelling correctness", "average word length", "average sentence length" and "numbers of clauses". "Type-token ratio", the relationship between the number of types and the number of tokens, is an important indicator to test lexical diversity.[11]

\section{Results and Analysis}

Data Comparison. Table 1 shows the data comparison between Group A and B, both of whom finished three writings respectively. One writing assignment was finished in the third week of an academic year, another was in the eighth week, and the other was in the twelfth week.

Table 1 Data comparison of first writing assignment

\begin{tabular}{|c|c|c|c|c|c|c|}
\hline Indicators & $\begin{array}{c}\text { Average } \\
\text { Times of } \\
\text { Revision }\end{array}$ & $\begin{array}{c}\text { Type-Token } \\
\text { Ratio }\end{array}$ & $\begin{array}{c}\text { Spelling } \\
\text { Correctness }\end{array}$ & $\begin{array}{c}\text { Average } \\
\text { Word } \\
\text { Length }\end{array}$ & $\begin{array}{c}\text { Average } \\
\text { Sentence } \\
\text { Length }\end{array}$ & $\begin{array}{c}\text { Numbers } \\
\text { of } \\
\text { Clauses }\end{array}$ \\
\hline $\mathrm{A}$ & 1.63 & 8.19 & 0.884 & 5.1 & 13.23 & 13.1 \\
\hline $\mathrm{B}$ & 13.53 & 10.45 & 0.925 & 5.6 & 15.98 & 16.6 \\
\hline
\end{tabular}

Table 2 Data comparison of second writing assignment

\begin{tabular}{|c|c|c|c|c|c|c|}
\hline Indicators & $\begin{array}{c}\text { Average } \\
\text { Times of } \\
\text { Revision }\end{array}$ & $\begin{array}{c}\text { Type-Token } \\
\text { Ratio }\end{array}$ & $\begin{array}{c}\text { Spelling } \\
\text { Correctness }\end{array}$ & $\begin{array}{c}\text { Average } \\
\text { Word } \\
\text { Length }\end{array}$ & $\begin{array}{c}\text { Average } \\
\text { Sentence } \\
\text { Length }\end{array}$ & $\begin{array}{c}\text { Numbers } \\
\text { of } \\
\text { Clauses }\end{array}$ \\
\hline A & 1.35 & 7.89 & 0.842 & 5.1 & 11.58 & 13.7 \\
\hline B & 13.62 & 10.63 & 0.955 & 5.9 & 15.45 & 17.5 \\
\hline
\end{tabular}

Table 3 Data comparison of third writing assignment

\begin{tabular}{|c|c|c|c|c|c|c|}
\hline Indicators & $\begin{array}{c}\text { Average } \\
\text { Times of } \\
\text { Revision }\end{array}$ & $\begin{array}{c}\text { Type-Token } \\
\text { Ratio }\end{array}$ & $\begin{array}{c}\text { Spelling } \\
\text { Correctness }\end{array}$ & $\begin{array}{c}\text { Average } \\
\text { Word } \\
\text { Length }\end{array}$ & $\begin{array}{c}\text { Average } \\
\text { Sentence } \\
\text { Length }\end{array}$ & $\begin{array}{c}\text { Numbers } \\
\text { of } \\
\text { Clauses }\end{array}$ \\
\hline $\mathrm{A}$ & 1.23 & 7.56 & 0.798 & 5.2 & 13.12 & 13.6 \\
\hline $\mathrm{B}$ & 13.13 & 12.11 & 0.955 & 5.9 & 16.25 & 18.8 \\
\hline
\end{tabular}


As can be seen from Table 1, 2 and 3, the average times of revision of Group B is more than 10 times of that of Group A, and furthermore, the highest times of revision of Group A is three while the highest of Group B is 114. In addition, other indicators of Group B are obviously higher than that of Group A. Both Groups had the same writing requirements and writing conditions, and the only difference is that Group A got all feedbacks from their teacher - the author of this paper while Group B got all feedbacks from Pigaiwang. Therefore, it can be concluded that the differences in their data mainly come from the different feedbacks.

Analysis of Questionnaire. Table 4 is the data compilation of the questionnaire survey conducted in Group B.

Table 4 Data of Questionnaire

\begin{tabular}{|l|c|c|c|c|c|}
\hline & $\begin{array}{c}\text { very } \\
\text { satisfactory }\end{array}$ & satisfactory & average & unsatisfactory & $\begin{array}{c}\text { very } \\
\text { unsatisfactory }\end{array}$ \\
\hline $\begin{array}{l}\text { Whether the feedback of } \\
\text { Pigaiwang is accurate? }\end{array}$ & $48.1 \%$ & $45.3 \%$ & $3.3 \%$ & $3.3 \%$ & $0.0 \%$ \\
\hline $\begin{array}{l}\text { Whether Pigaiwang } \\
\text { helps to repeated } \\
\text { writing? }\end{array}$ & $55.0 \%$ & $38.3 \%$ & $6.7 \%$ & $0.0 \%$ & $0.0 \%$ \\
\hline $\begin{array}{l}\text { Whether Pigaiwang } \\
\text { promotes the learning of } \\
\text { vocabulary and } \\
\text { sentences? }\end{array}$ & $48.3 \%$ & $41.7 \%$ & $10.0 \%$ & $0.0 \%$ & $0.0 \%$ \\
\hline $\begin{array}{l}\text { Whether Pigaiwang } \\
\text { lowers writing anxiety? }\end{array}$ & $26.7 \%$ & $46.7 \%$ & $23.3 \%$ & $3.3 \%$ & $0.0 \%$ \\
\hline $\begin{array}{l}\text { Whether Pigaiwang } \\
\text { increases writing } \\
\text { interest? }\end{array}$ & $14.7 \%$ & $26.7 \%$ & $33.3 \%$ & $20.0 \%$ & $5.3 \%$ \\
\hline $\begin{array}{l}\text { Whether Pigaiwang } \\
\text { heightens the sense of } \\
\text { achievement? }\end{array}$ & $19.1 \%$ & $33.3 \%$ & $33.3 \%$ & $14.3 \%$ & $0.0 \%$ \\
\hline
\end{tabular}

The above feedbacks show that students in Group B are generally satisfied with Pigaiwang. To further find out their comments on Pigaiwang, the author of this paper interviewed three students from Group B. Their comments are: Student Jiang thought Pigaiwang had good performance in the above six aspects but due to his own laziness he only revised for 2 times; Student Lee thought she had learnt and acquired a lot from Pigaiwang and suggestion given by it was more specific and accurate than traditional scoring; Student Chen said that the feedbacks given by Pigaiwang was timely and helped to promote continuous revision and what's more without the comments from teachers writing became easier and more relaxed.

Analysis of Functions of Pigaiwang. The main functions which help students' self-learning include: vocabulary learning such as "Study Notes", "Synonym" and "Recommended Expressions" (as Fig. 1 shows); "Ranking" which promotes students' times of revision in order to get a better ranking; sentences learning such as "Shining Phrases" and "Splendid Sentences" (as Fig. 2 shows); sample reading such as "Recommended Writing" and "Model Essay". 


\begin{tabular}{|c|c|}
\hline \multirow{5}{*}{$\begin{array}{l}\text { There is no choice for us whether we like or we } \\
\text { want to learn. [comment] }\left[\begin{array}{ll}0 & 0\end{array}\right.\end{array}$} & [Study Notes] confusing words: choice, \\
\hline & alternative, preference, option, selection, \\
\hline & Good Wrong \\
\hline & [Recommended Expressions] \\
\hline & $\begin{array}{l}\text { otherwise/ if not/ before } \\
\text { Good Wrong }\end{array}$ \\
\hline $\begin{array}{l}\text { But in college, our major is the one that we } \\
\text { chose by ourselves according to our will and }\end{array}$ & $\begin{array}{l}\text { [Synonym] "according to" is synonymous with } \\
\text { "in accordance with" }\end{array}$ \\
\hline 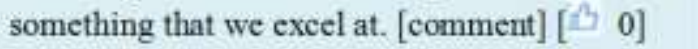 & Good Wrong \\
\hline
\end{tabular}

Figure 1. Screenshot of Vocabulary Learning

\author{
When it comes to the topic of happiness, \\ everybody has his own interpretation.$$
\text { [comment] [ } 0 \text { 0] }
$$

What's more, when acquiring the knowledge that I have never acquired also makes me feel happy. [comment] [ 0 ]

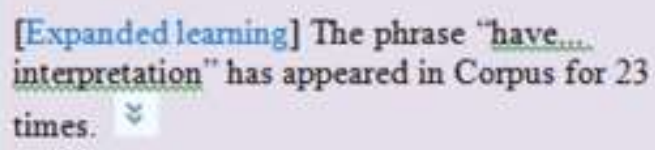

[Expanded Leaming] The expression "acquire. knowledge" has appeared in Corpus for 37 times.

Figure 2. Screenshot of Expanded Learning

\section{Conclusions}

This study shows that Pigaiwang effectively promotes students' self-learning through writing, which can be seen from the following aspects: first, timeliness helps students to repeatedly revise their writings and also promotes their continuous writing. In the writing process, effective feedback is such an important and necessary factor that we cannot ignore it in writing.[12] The three ways of feedbacks provided by Pigaiwang: system feedback, peer feedback and teacher feedback, is a reflection of process writing. Through continuous, multi-way of and multi-dimensional feedbacks writers are able to write continuously, which shows writing is a process rather than a result. In addition, ranking also promotes students' automated writing abilities.

Pigaiwang also promotes students' self-learning in vocabulary, grammar and sentences. The suggestion given on the website helps students to discover new language rules and learn on their own. Applying discovery skills learners could learn on their own and effectively acquire new knowledge.[13]

What's more, Pigaiwang helps students acknowledge their identity "writers". The aim of writing is reading. Compared with traditional time-consuming writing assessment, Pigaiwang could provide feedbacks immediately, specifically and accurately, which is a key factor for role identity, for it promotes internalization through inner and outer communication.[14]

Pigaiwang effectively lowers writing anxiety, promotes writing interest and heightens the sense of achievement, which also helps to promote students' continuous automated writing. If people know their behavior will bring about their expected outcomes and think they have enough abilities to accomplish, they will successfully perform a task.[15] From the analysis of datum and interview the study shows that under the guidance of Pigaiwang students have the abilities to revise their 
writing repeatedly. Without the pressure from their teacher, through interaction with computers, students can clearly see their growth which shows in the ranking and scores, which in the end promotes their writing interest and sense of achievement.

\section{Reference}

[1] Valenti S, Neri F \& Cucchiarelli A. An Overview of Current Research on Automated Essay Grading [J]. Journal of Information Technology Education, 2003 (2): 319-330.

[2] Alderson, J., Clapham, C., \& Wall, D. Language Test Construction and Evaluation [M]. Cambridge: Cambridge University Press, 1995.

[3] Liang Maocheng, Wen Qiufang. Acritical Review and Implications of Some Automated Essay Scoring Systems [J]. Computer-assisted Foreign Language Education, 2007, 10(117): 18.

[4] He Xuliang. Reliability and Validity of the Assessment by the Pigaiwang on College Students' Writings[J]. Modern Educational Technology, 2013, 23(5): 64-65.

[5] Chen Zhiwei. "The Innovation Center of Linguistic Intelligence and Technology Application" Has Been Set up in Beijing[EB/OL] (2013-11-21) [2017-10-18]. http://www.jyb.cn/high/gdjyxw/201311/t20131121_560472.html.

[6] Neman, B. S. Teaching Students to Write [M]. New York: Oxford University Press, Inc., 1995.

[7] Ferris, D. \& J. S. Hedgcock. Teaching ESL Composition: Purpose, Process, and Practice [M]. Mahwah, NJ: Lawrence Erlbaum, 2005.

[8] Bruner, J. S. The Process of Education [M]. Cambridge, Mass.: Harvard University Press, 1977: 20.

[9] Erikson, E. H. (1963). Childhood and Society [M]. New York: Norton, 1994.

[10] Nugent, Pam M.S. TYPE-TOKEN RATIO (TTR) [EB/OL] (2013-4-29) [2017-10-19]. https://psychologydictionary.org/type-token-ratio-ttr/.

[11]Douglas Biber. Methodological Issues Regarding Corpus-Based Analyses of Linguistic Variation [J]. Literary and Linguistic Computing, 1990 (5): 257-269.

[12] Keh, C. L. Feedback in the Writing Process: A Model and Methods from Implementation [J]. ELT Journal, 1990 (4): 302.

[13]Bruner, J. S.. The Process of Education [M]. Cambridge, Mass.: Harvard University Press, 1977: 51.

[14] Ygotsky, L. S. Mind in Society: The Development of Higher Psychological Processes [M]. Cambridge: Harvard University Press, 1978:85.

[15] Bandura, A. Self-Efficacy: toward a Unifying Theory of Behavioral Change [J]. Psychological Review, 1977(84): 207. 